\title{
Main Determinants Influencing Inward and Outward Foreign Direct Investments in Thailand: Comparisons and Vital Implications
}

\author{
*Hsiang-Hsi Liu" ${ }^{1}$ Pitprapha Dejphanomporn² ${ }^{2}$ and Guan-Ting Liu ${ }^{3}$
}

\begin{abstract}
Foreign direct investment (FDI) has played an important role in the evolution of globalization and is the cornerstone of industrial expansion and economic development. From 1988 to 1990 till now, Thailand has been one of the main destinations of FDI, namely inward FDI (IFDI). However, outward foreign direct investment (OFDI) increased rapidly from 2003 to 2011, and it continues to grow. Although initially a net importer, Thailand has transformed into a net exporter of direct investment in 2011. Since 2003, Thailand has entered a stage of re-emergence of OFDI, and this growth trend of OFDI will continue in the future. The purpose of this study is to investigate the main determinants of Thailand's IFDI and OFDI, and apply a panel data model to determine which determinants have a significant impact on Thailand's IFDI and OFDI. We considered the FDI flows between Thailand and its five FDI partners (Japan, Hong Kong, the Netherlands, Singapore and the United States) from 1997 to 2014, where IFDI was 1997-2014, and 2004-2014 was OFDI. Regarding the determinants of Thailand's IFDI and OFDI, the market size (relative per capita GDP), Thailand's openness, relative R\&D intensity and bilateral trade agreements have a positive impact on FDI decisions for both IFDI and OFDI. Relative wages and geographic distance have opposite effects on Thailand's IFDI and OFDI. Specifically, our empirical results show that market size is the most important determinant of IFDI inflows into Thailand, while the most important determinant of Thai OFDI is bilateral trade agreements.
\end{abstract}

JEL classification numbers: F14, F23, F43.

Keywords: Foreign Direct Investment, Panel Data Model, Fixed Effects, Generalized Least Squares (GLS).

\footnotetext{
${ }^{1,2}$ Graduate Institute of International Business, National Taipei University, Taiwan.

${ }^{3}$ Department of Shipping and Transportation Management, National Taiwan Ocean University,

Taiwan.

Article Info: Received: September 23, 2021. Revised: October 23, 2021.

Published online: November 8, 2021.
} 


\section{Introduction}

Foreign direct investment (FDI) has played an important role in the evolution of globalization and is the cornerstone of industrial expansion and economic development. From 1988 to 1990 till now, Thailand has been one of the main destinations of FDI, namely inward FDI (IFDI). However, outward foreign direct investment (OFDI) grew rapidly from 2003 to 2011, and it continues to grow.

According to the UNCTAD World Investment Report 2013, Thailand was one of the eight priority destinations for foreign investment during the period 2013-2015, and the seventh largest recipient of foreign direct investment in East Asia and Southeast Asia. According to a report by the Board of Investment of Thailand (BOI), Thailand's largest IFDI in 2013 were Japan, Hong Kong, the Netherlands, Malaysia, Singapore and the United States. The main areas of foreign investment are metallurgy and machinery, electronic and electrical products, services, and paper and chemical products. Despite internal political tensions and severe floods in 2011, Thailand has succeeded in its efforts to maintain an open, market-oriented economy and has inspired IFDI as a means to promote economic development, employment and technology transfer. In recent decades, Thailand has been a major destination for foreign direct investment, and hundreds of foreign companies have successfully invested in Thailand.

As more and more Thai companies become global business competitors, they are facing limitations and challenges, and they need to optimally combine long-term business strategies and government support to overcome the problems of mutual action and reduce transaction costs. Therefore, the increasing internationalization of Thai companies has a wide-ranging impact on Thai industry in terms of upgrading factors and international competitiveness. When the domestic market becomes too saturated, encouraging foreign direct investment may be one of the good measures to provide Thai companies with better opportunities. The main motivation of OFDI is to seek resources, seek markets and seek efficiency or seek strategic assets, including expanding market scope, supporting distribution and expanding trade channels (Wee, 2007). According to Wee (2007) and Chantapong and Thanabodee (2012), Thailand's OFDI can be divided into four stages. In the early stage, foreign direct investment was restricted due to the restrictions on foreign direct investment, and only a few Thai multinational companies were able to conduct business abroad (Dacharux, Leelapornchai and Udomkerdmongkol, 2009). However, in recent years, Thailand has increased its OFDI to major FDI destinations in the United States, Hong Kong, Singapore and Japan. This investment is also concentrated in financial institutions in Hong Kong and Singapore. For canned and frozen foods, the investment destination is the United States (Pongpattananon and Annonjarn, 2012).

Thailand is facing tremendous growth in both the inflow and outflow of foreign direct investment globally. This explosive growth has attracted scholars and researchers to devote more energy to understanding the empirical relationship between a country's growth and FDI. In addition, as a member of the ASEAN 
Economic Community (AEC), Thailand will need more foreign direct investment into the world economy and strengthen the economic, social and political relations between the ASEAN Economic Community countries and the rest of the world. This also shows that it is very important to determine the main determinants of Thailand's IFDI and OFDI for future government and business policies. Regarding the literature on Thailand's IFDI and OFDI, there is little research on its determinants (Pananond, 2007; Sermcheep, 2013). Even research that considers Thailand's inward or outward FDI is considered a unilateral perspective, that is, a single industry within two countries or countries (Masron and Shahbudin, 2010; Passakornjaras, 2012; Poomlamjiak, 2013). Therefore, this study aims to use the data provided for each country and year to clarify the determinants of Thailand's bilateral investment in inward or outward FDI. In order to conduct a more complete study on the determinants of Thailand's IFDI and OFDI, this study will specify an empirical model that allows the use of panel data from different countries to detect factors that affect Thailand's IFDI and OFDI in order to set up more appropriate model and obtain more realistic information for FDI decision-making.

The remainders of this study are organized as follows. Section 2 describes model specifications, variable descriptions, and predicted relationships. Section 3 discusses the empirical results and implications. This study then provides concluding remarks in Section 4.

\section{Model Specification, Variable Description and Predicted Relationships}

Based on relevant FDI theories and literature, such as Dunning, (1993), Buckley, Clegg and Wang (2006), Thanyakhan (2008), Hill and Jongwanich (2009), Masron, and Shahbudin (2010), Passakornjaras (2012), Leibrecht And Riedl (2014) and Nnamdi and Eniekezimene (2018). Obviously, when selecting variables, we focus on the determinants (variables) that are actually related to the main source countries of IFDI and OFDI. The model specification and predicted relationships are discussed below.

\subsection{Model Specification}

In this section, we will provide an overview of the econometric model, and then discuss the variables, their measurements, and expected effects. The themes set by Model 1 and Model 2 can refer to our earlier research, such as "Liu and Dejphanomporn (2017 and 2018). 


\subsubsection{Model 1 (IFDI in Thailand)}

LIFDI=f (LRGDP, LTOPEN, LRWage, LREX, LDIST, LRD, TBA, PR, D97, D0814, $\mathrm{D}, \mathrm{T})$

The dynamic panel data model is utilized to incorporate the time-series and the cross-sectional aspects of the five countries under studies.

$$
\begin{aligned}
\text { LIFDI }_{j t}= & \beta_{0} \\
& +\beta_{1} L R G D P_{j t}+\beta_{2} L_{T O P E N_{j t}}+\beta_{3} L_{R W a g e}+\beta_{4} L R E X_{j t} \\
& +\beta_{5} L D I S T_{j t}+\beta_{6} L R D_{j t}+\beta_{7} T B A_{j t}+\beta_{8} P R_{j t}+\beta_{9} \mathrm{D} 97 \\
& +\beta_{10} D 8014+\sum_{j=11}^{14} \beta_{j} D_{j t}+\beta_{15} T_{j t}+\varepsilon_{j t}
\end{aligned}
$$

The expected signs of the coefficients are:

$\beta_{1}>0, \beta_{2}>0, \beta_{3}<0, \beta_{4}<0, \beta_{5}<0, \beta_{6}>0, \beta_{7}>0, \beta_{8}<0, \beta_{9}<0, \beta_{10}<0$

\section{Where}

LIFDI $I_{\mathrm{j}}$ : Inward FDI, annual inflows of real FDI into Thailand from country $\mathrm{j}$

j: Country (Japan, Hong Kong, the Netherlands, Singapore, the United States)

t: Time (1997-2014).

LRGDP $_{\mathrm{jt}}$ : Market size, relative of per capita GDP between Thailand and home countries.

LTOPEN $_{\mathrm{jt}}$ : Openness, ratio of Thailand's exports plus imports to GDP products.

LRWagejt: Relative wage rate, relative real wages between Thailand and home countries.

LREX $_{\mathrm{jt}}$ : Relative exchange rate, relative exchange rates between Thailand and home countries.

LDIST $_{\mathrm{j} \mathrm{t}}$ : Geographical distance, distances between Thailand and home countries

$L_{R D}$ t: Relative $R \& D$ intensity, relative $R \& D$ intensity of Thailand and home countries.

TBAjt: Bilateral trade agreement, the number of bilateral agreements signed by Thailand.

PRjt: Dummy variable for political risks in Thailand, where the dummy variable is equal to 1 for periods of severe risk $(2004,2009,2013-2014)$ and 0, otherwise.

D97: Dummy variable for Asia Financial Crisis 1996-1998, where the dummy variable is equal to 1 for Asian Financial Crisis (1996-1998) and 0, otherwise.

D0814: Dummy variable for Global Financial Crisis, Subprime Mortgage and Financial Tsunami 2008-2014, where the dummy variable is equal to 1 for Subprime Mortgage and Financial Tsunami (2008-2014), and 0, otherwise.

$\mathrm{D}_{\mathrm{jt}}$ : Dummy variable for country factors, where 1 Japan and 0 otherwise; 1 , Netherlands and 0 otherwise; 1 Singapore and 0 , otherwise; 1 , US and 0 , otherwise $\mathrm{T}_{\mathrm{jt}}$ : Time trend.

$\varepsilon_{\mathrm{jt}}$ : Disturbance terms, $\varepsilon_{\mathrm{jt}} \sim \mathrm{iid} \mathrm{N}\left(0, \sigma^{2}\right)$. 


\subsubsection{Model 2 (Outward FDI from Thailand)}

LOFDI=f (LRGDP, LTOPEN, LRWage, LREX, LDIST, LRD, TBA, D0814, D, T) The dynamic panel data model is utilized to incorporate the time-series and the cross-sectional aspects of the five countries under studies.

$$
\begin{aligned}
\text { LOFDI }_{j t}= & \beta_{0}+\beta_{1} L R G D P_{j t}+\beta_{2} L_{T O P E N_{j t}}+\beta_{3} L_{R W a g e_{j t}}+\beta_{4} L R E X_{j t} \\
& +\beta_{5} L D I S T_{j t}+\beta_{6} L R D_{j t}+\beta_{7} T B A j t+\beta_{8} D 0814 \\
& +\sum_{j=9}^{12} \beta_{j} D_{j t}+\beta_{13} T_{j t}+\varepsilon_{j t}
\end{aligned}
$$

The expected signs of the coefficients are:

$\beta_{1}>0, \beta_{2}>0, \beta_{3}<0, \beta_{4}<0, \beta_{5}<0, \beta_{6}>0, \beta_{7}>0, \beta_{8}<0$

Where

LOFDI $\mathrm{j}_{\mathrm{j}}$ : the annual outflows of Thailand's real FDI to country $\mathrm{j}$

j: Country (Japan, Hong Kong, the Netherlands, Singapore, the United States)

t: Time (2004-2014)

LRGDP $_{\mathrm{jt}}$ : Market size, relative per capita GDP between host countries and Thailand LTOPEN $_{\mathrm{jt}}$ : Openness, ratio of Thailand's exports plus imports to GDP

LRWage jt: Relative wage rate, relative real wages between host countries and Thailand

LREX $_{\mathrm{jt}}$ : Relative exchange rate, relative exchange rates between host countries and Thailand

LDIST $_{\mathrm{jt}}$ : Geographical distance, distances between host countries and Thailand LRD $_{\mathrm{jt}}$ : Relative R\&D intensity, R\&D intensity between host countries and Thailand TBA $_{\mathrm{jt}}$ : Bilateral trade agreement, the number of bilateral agreements signed by Thailand

D $0814:$ Dummy variable for Global Financial Crisis, Subprime Mortgage and Financial Tsunami 2008-2014, where the dummy variable is equal to 1 for Subprime Mortgage and Financial Tsunami (2008-2014), and 0, otherwise

$\mathrm{D}_{\mathrm{jt}}$ : Country factors, where $1=$ Japan, $0=$ Otherwise; $1=$ Netherlands, $0=$ Otherwise; $1=$ Singapore, $0=$ Otherwise; $1=$ United States, $0=$ Otherwise $\mathrm{T}_{\mathrm{jt}}$ : Time trend

$\varepsilon_{\mathrm{jt}}$ : Disturbance terms, $\varepsilon_{\mathrm{jt}} \sim \mathrm{iid} \mathrm{N}\left(0, \sigma^{2}\right)$

Based on the Model 1 and Model 2 we discussed above, a log-linear model is proposed; therefore, the variable data is converted to a natural logarithm because we anticipate the nonlinearity in the relationship based on theory and previous empirical work. 


\subsection{Variable Description and Predicted Relationships}

This research focuses on countries that have a more realistic influence through Thailand's outstanding inward and outward investment countries. We considered the FDI flows between Thailand and its five FDI partners (Japan, Hong Kong, the Netherlands, Singapore and the United States) during the period 1997-2014, where IFDI was 1997-2014, and OFDI was 2004-2014.

\subsubsection{Explained Variable}

\section{Defining and Measures of IFDI (LIFDI $\left.\mathrm{I}_{\mathbf{j} t}\right)$ and OFDI (LOFDI $\left.\mathbf{j}_{\mathbf{j}}\right)$}

In this research, we use the panel data model for empirical research. Here, LIFDI ${ }_{\mathrm{jt}}$ represents the FDI inflows into Thailand from Japan, Hong Kong, the Netherlands, Singapore, and the United States during the 2004-2014 periods. LOFDI $\mathrm{j}_{\mathrm{jt}}$ represents the amount of foreign direct investment from Thailand to each country of interest during 2004-2014: Japan, Hong Kong, the Netherlands, Singapore and the United States. We use the statistical size of FDI in and out of Thailand from the Bank of Thailand (BOT) website, and then calculate the logarithm of the stable transformation of variance.

\subsubsection{Explanatory Variables Market Size (LRGDP jt $_{\text {t }}$}

Market size is the main attraction for investors to enter new markets. The market size is widely regarded as one of the main determinants of IFDI and OFDI. In many studies on the determinants of FDI (Masron and Shahbudin, 2010; Nnamdi and Eniekezimene, 2018; Jaiblai and Shenai, 2019), we often find that market size is the most important determinant. Per capita GDP is used as an indicator to measure the potential of the host country's domestic market. This study will use the relative per capita GDP between the FDI host country and the home country $\left(\right.$ LRGDP $_{\mathrm{jt}}$ ) to show the impact of market size on Thailand's IFDI and OFDI. It is expected that it will become a positive and significant determinant of IFDI and OFDI.

\section{Thailand's Openness (LTOPEN ${ }_{\mathrm{jt}}$ )}

A country's openness can be determined by its imports and exports. Openness means how a country lowers barriers to entry for foreigners; therefore, this study will consider the degree of openness in Thailand $\left(\right.$ LTOPEN $_{\mathrm{jt}}$ ). Masron and Shahbudin (2010) found mixed evidence on the importance of openness when determining IFDI and OFDI, which is mainly measured by the ratio of exports plus imports to GDP. Economic conditions for a better investment climate are likely to overlap with conditions for a better international trade environment, or trade flows are correlated with investment flows (Ng, 2010; Jaiblai and Shenai, 2019). It is expected that Thailand's degree of openness may have a positive impact on its IFDI and/or OFDI (Abbas and Mosallamy, 2016). 


\section{Relative Wage rate (LRWage ${ }_{j t}$ )}

Wage costs have been regarded as one of the most prominent indicators of IFDI and OFDI. This study will focus on the relative labor wage rate (LRWage ${ }_{j t}$ ) of the host country and Thailand. Masron and Shahbudin (2010) and Daly and Tosompark (2011) show that higher wage discourages FDI. Hence, Relative wage costs are expected to have a negative impact on Thailand's IFDI and OFDI.

\section{Relative Exchange rate (LREX $\left.\mathbf{X}_{\mathbf{j t}}\right)$}

When a firm wishes to invest in a country, the strength of the currency (the exchange rate) is used as a measure of the level of inflation and the purchasing power of the investing company. This study focuses on the effect of the relative exchange rate between host country and home country $\left(\mathrm{LREX}_{\mathrm{jt}}\right)$ on IFDI and OFDI. Currency depreciation will reduce exchange rate risk. As the host country's currency appreciates, investors' purchasing power in foreign currency terms diminishes; Therefore, we expect a negative relationship between the value of currency and Thailand's FDI flows (Masron and Shahbudin, 2010; Jaiblai and Shenai, 2019).

\section{Geographical Distance (DIST $\mathbf{j}_{\mathbf{j}}$ )}

This study will use the distance between Thailand and the export port of FDI's home country to determine the geographical distance (DIST $\mathrm{jt}_{\mathrm{j}}$ ), as shown by Trkulja (2005) and Egger (2008). If the distance between the two increases, the cost of transporting goods and services will increase, while the historical, cultural and institutional context, as well as communication and management styles, arising from geographical distance may influence FDI decisions (Jaiblai and Shenai, 2019). Therefore, we expect a negative relationship between geographical distance and Thailand's FDI inflow and outflow.

\section{Relative R\&D Intensity ( LRD $\left._{\mathbf{j t}}\right)$}

The higher the technological capacity of R\&D investment, the more extensive FDI, especially the FDI of enterprises or countries to industrial countries. As predicted by the internalized FDI theory (Tomiura, 2003), firms with rich human skills tend to have a majority stake in FDI in host countries such as Thailand. Developing countries, such as Thailand, need to stimulate research and development to attract FDI, while higher production technology and creativity can improve their own manufacturing capacity and lead more FDI from other countries. The relative R\&D intensity $\left(L R D_{j t}\right)$ here is the R\&D intensity between the host country and the home country. Therefore, we expect a positive relationship between R\&D intensity and Thailand's IFDI and OFDI.

\section{Bilateral Trade Agreement Signed by Thailand $\left(\mathrm{TBA}_{\mathrm{jt}}\right)$}

This study focuses on the number of bilateral agreements signed by Thailand because trade agreements between countries can attract FDI. The bilateral trade agreement signed between the two countries $\left(\mathrm{TBA}_{\mathrm{jt}}\right)$ makes negotiation quite easy and gives the two countries a common preferential trade status (Passakornjaras, 
2012). Therefore, we expect the bilateral trade agreement to have a positive impact on Thailand's IFDI and OFDI.

\section{Political Risks in Thailand (PR $\mathbf{\text { jt }})$}

Over the past decade, Thailand has faced many political controversies, which have led to an unstable economic and financial situation. Political risks $\left(\mathrm{PR}_{\mathrm{jt}}\right)$ include internal and external conflicts, corruption, ethnic tensions, the extent of the rule of law, democratic accountability in government, and the quality of bureaucracy. That could deter FDI inflows. The study of Abbas and Mosallamy (2016) found that countries with high political risk had lower FDI inflows. Political risk is therefore expected to have a negative impact on Thailand's FDI inflows. Here, we use a dummy variable as a proxy for political risk $\left(\mathrm{PR}_{\mathrm{jt}}\right)$ in Thailand, where Crisis $=1$ for the years 2004, 2009 and 2013-2014; Crisis =0 otherwise. The value of 1 in a specific year represents and runs the political risk variable that occurred in those years to detect the reduction of Thailand's IFDI, while other years have no such impact because they are not faced with political risk, so the values are set 0 .

\section{Asia Financial Crisis1996-1998 (D97)}

Beginning in July 1997, the Asian financial crisis has swept across most parts of East Asia, causing people to worry about financial contagion leading to the collapse of the global economy. Therefore, we expect a negative relationship between the Asian financial crisis (D97) and FDI inflows in Thailand. In order to capture the impact of the Asian financial crisis on Thailand's IFDI, we use a dummy variable as a proxy for the Asian financial crisis, where Crisis=1 during 1996-1998, otherwise it is 0 .

\section{Global Financial Crisis (D0814)}

The financial tsunami of 2007-2008 is also known as the global financial crisis. It threatened the total collapse of large financial institutions, which governments prevented with bailouts, but global financial markets and economies continued to deteriorate. Therefore, the subprime mortgage crisis and financial tsunami from 2008 to 2014 ( $\mathrm{D}_{0814}$ ) are expected to have a negative impact on both IFDI and OFDI. In order to consider the impact of the subprime mortgage crisis and financial tsunami on IFDI and OFDI in Thailand, dummy variables were used, where Crisis=1 during 2008-2014, otherwise 0 .

\section{Country factors $\left(\mathbf{D}_{\mathbf{j t}}\right)$}

In order to consider the influence of country factor on IFDI and OFDI of Thailand, we use dummy variables $\left(\mathrm{D}_{\mathrm{jt}}\right.$, where $1=\mathrm{Japan}, 0=$ Otherwise; $1=$ Netherlands, $0=$ Otherwise; $1=$ Singapore, $0=$ Otherwise; $1=\mathrm{US}, 0=$ Otherwise) as proxies for country effects to control for country-specific fixed effects, such as investment subsidies, tax regimes or culture and language (Dunning, 1993). 


\section{Time-Trend $\left(\mathbf{T}_{\mathbf{j} t}\right)$}

In order to consider the temporal trend effect for Thailand's IFDI from host countries (Japan, Hong Kong, the Netherlands, Singapore and the United States), we used the trend variable ( $\mathrm{T}_{\mathrm{jt}}$ for $\mathrm{t}=1997-2014$ ) as a proxy for the temporal trend effect. Meanwhile, the temporal trend effect of Thailand's OFDI on the host countries (Japan, Hong Kong, the Netherlands, Singapore and the United States), the trend variable $\left(\mathrm{T}_{\mathrm{j} t} ; \mathrm{t}=2004-2014\right)$ was used as a proxy for the temporal trend effect.

The summary of measurement, predicted effects and data sources for all determinants are given in Appendices A and B.

\section{Empirical Results and Implications}

In this section, we present the results of the econometric model and explore which of the above results are supported by statistical data. Basic statistics are estimated using the SAS computer program. The generalized least squares (GLS) method is applied to estimate the coefficients of our specified model to obtain the empirical results.

\subsection{Data Descriptions}

Descriptive statistical summaries of variables expressed in model 1 (IFDI in Thailand) and Model 2 (OFDI in Thailand) are converted into natural logarithms, including mean, standard error, skewness and kurtosis, as shown in Table 1. The statistical data of the variables explaining Thailand's IFDI or describing Thailand's OFDI showed that the mean values of each variable are significantly different, while the standard errors of LREX, LRGDP and LDIST are all higher than other variables. The sample skewness statistics of most variables LRWage, LDIST, LOFDI, LRGDP, LREX, LDIST and LRD in Model 1 and Model 2 are non-negative. The sample kurtosis statistic is less than 3. Both sample skewness and kurtosis statistics represent the distribution pattern of each variable in this research.

\subsection{Panel Unit Root Tests and Model Selection}

In order to avoid considering spurious relationships that would lead to misinterpretation of empirical results, the time series of variables in model 1 (Thailand's IFDI) and model 2 (Thailand's OFDI) of this study need to be tested for stationarity using LLC (Levin, Lin, and Chu, 2002) and IPS (Im, Pesaran and Shin, 2003) panel unit root tests. The results of the LLC and IPS unit root tests are shown in Table 2, which indicates that all variable series are stationary, suggesting that the results of the empirical model do not appear to be spurious. 
al.

Table 1: Descriptive Statistics of Dependent and Independent Variables in Inward and Outward FDI Panel Data Model

\begin{tabular}{|c|c|c|c|c|c|c|c|}
\hline \multicolumn{8}{|c|}{ Model 1 (IFDI in Thailand) } \\
\hline & LIFDI & LRGDP & LTOPEN & LRWage & LREX & LDIST & LRD \\
\hline Mean & 2.8193 & 2.2971 & 2.1092 & 1.7093 & 3.9725 & 3.6351 & -0.9115 \\
\hline Std. Dev. & 0.4794 & 0.7693 & 0.0593 & 0.2878 & 0.8163 & 0.4016 & 0.2609 \\
\hline Skewness & -0.7824 & -0.3104 & -0.7968 & 0.9341 & -0.8600 & 0.0090 & 0.9070 \\
\hline Kurtosis & 2.3343 & -1.5346 & -0.3016 & -0.4057 & -0.7047 & -1.6994 & 0.2390 \\
\hline Observation: & all series i & he IFDI samp & period are 90 & & & & \\
\hline \multicolumn{8}{|c|}{ Model 2 (OFDI in Thailand) } \\
\hline & LOFDI & LRGDP & LTOPEN & LRWage & LREX & LDIST & LRD \\
\hline Mean & 4.0101 & 3.6476 & 2.1445 & 1.7112 & 2.0249 & 3.6351 & -0.9191 \\
\hline Std. Dev. & 0.0237 & 0.7498 & 0.0325 & 0.3064 & 0.8236 & 0.4031 & 0.2297 \\
\hline Skewness & 1.3892 & 0.3299 & -1.0718 & 0.9630 & 0.8428 & 0.0091 & 1.0002 \\
\hline Kurtosis & 2.5917 & -1.5315 & 0.2089 & -0.3666 & -0.7431 & -1.7174 & -0.2483 \\
\hline
\end{tabular}


Main Determinants Influencing Inward and Outward Foreign Direct Investments in ... 11

Table 2: Panel Unit Root Test for Variables in Model 1 (IFDI in Thailand) and Model 2 (OFDI in Thailand)

\begin{tabular}{|c|c|c|c|c|}
\hline & None & With drift & $\begin{array}{l}\text { With drift and } \\
\text { time trend }\end{array}$ & $\begin{array}{l}\text { Maximum } \\
\text { lag Period }\end{array}$ \\
\hline \multicolumn{5}{|c|}{ Model 1 (IFDI in Thailand) } \\
\hline \multicolumn{5}{|c|}{ LLC unit root test } \\
\hline LIFDI & $-13.5392 * * *$ & $-13.1057 * * *$ & $-13.9541 * * *$ & [4] \\
\hline LRGDP & $-12.9083 * * *$ & $-12.6394 * * *$ & $-13.4587 * * *$ & [4] \\
\hline LTOPEN & $-10.6530 * * *$ & $-9.8316 * * *$ & $-10.0029 * * *$ & [4] \\
\hline LRWage & $-12.6056 * * *$ & $-9.8897 * * *$ & $-10.1826 * * *$ & [4] \\
\hline LREX & $-11.4968 * * *$ & $-10.9771 * * *$ & $-11.5547 * * *$ & [4] \\
\hline LDIST & $-12.9083 * * *$ & $-12.6394 * * *$ & $-13.4587 * * *$ & [4] \\
\hline LRD & $-11.2002 * * *$ & $-10.1079 * * *$ & $-10.5249 * * *$ & [4] \\
\hline \multicolumn{5}{|c|}{ IPS unit root test } \\
\hline LIFDI & & $-14.6530 * * *$ & $-14.8391 * * *$ & {$[4]$} \\
\hline LRGDP & & $-14.3191 * * *$ & $-14.7755 * * *$ & [4] \\
\hline LTOPEN & & $-12.6005 * * *$ & $-12.7747 * * *$ & [4] \\
\hline LRWage & & $-12.1578 * * *$ & $-12.3640 * * *$ & [4] \\
\hline LREX & & $-12.6645 * * *$ & $-12.8041 * * *$ & [4] \\
\hline LDIST & & $-14.3191 * * *$ & $-14.7755 * * *$ & [4] \\
\hline LRD & & $-12.5851 * * *$ & $-12.6857 * * *$ & [4] \\
\hline \multicolumn{5}{|c|}{ Model 2 (OFDI in Thailand) } \\
\hline \multicolumn{5}{|c|}{ LLC unit root test } \\
\hline LOFDI & $-9.3140 * * *$ & $-8.2676 * * *$ & $-6.1307 * * *$ & [4] \\
\hline LRGDP & $-6.2574 * * *$ & $-5.3029 * * *$ & $-5.0203 * * *$ & [4] \\
\hline LTOPEN & $-8.2807 * * *$ & $5.2729 * * *$ & $7.6376^{* * *}$ & [4] \\
\hline LRWagetj & $-10.9243 * * *$ & $-7.2165 * * *$ & $-6.6864 * * *$ & [4] \\
\hline LREX & $-8.1846 * * *$ & $-4.7065 * * *$ & $-4.2407 * * *$ & [4] \\
\hline LDIST & $-4.7282 * * *$ & $-2.3741 * * *$ & $-2.7998 * * *$ & [4] \\
\hline LRDtj & $-14.3496 * * *$ & $-12.1706 * * *$ & $-11.6714 * * *$ & [4] \\
\hline \multicolumn{5}{|c|}{ IPS unit root test } \\
\hline LOFDI & & $-10.5342 * * *$ & $-10.4206 * * *$ & [4] \\
\hline LRGDP & & $-8.4057 * * *$ & $-8.3262 * * *$ & [4] \\
\hline LTOPEN & & $-5.9984 * * *$ & $-5.4859 * * *$ & [4] \\
\hline LRWagetj & & $-9.9714 * * *$ & $-9.8043 * * *$ & [4] \\
\hline LREX & & $-8.0320 * * *$ & $-7.7190 * * *$ & [4] \\
\hline LDIST & & $-4.4824 * * *$ & $-3.7604 * * *$ & [4] \\
\hline LRDtj & & $-13.5064 * * *$ & $-13.6492 * * *$ & {$[4]$} \\
\hline
\end{tabular}

Note: $* * *$ denotes statistical significance at the $1 \%$ level. Brackets [ ] indicate the variables of AIC maximum lag. 
al.

Based to Table 3, the F test rejects the null hypothesis and implies that fixed effects models are more appropriate than ordinary least squares (OLS) models. Based on the results of Breusch-Pagan LM test, the random effect model is better than the OLS model. Therefore, we use the Hausman test to compare the fixed effects model with the random effects model, and find that the fixed effects model is superior to the random effects model for both model 1 and Model 2.

Table 3: Selections for OLS, Fixed and Random Effects Results of Model 1 and Model 2

\begin{tabular}{|c|c|c|c|}
\hline \multicolumn{4}{|c|}{ Model 1 (IFDI in Thailand) } \\
\hline & F Test & LM test & Hausman test \\
\hline \multirow{3}{*}{$\begin{array}{c}\frac{\text { Hypothesis }}{\mathrm{H}_{0}:} \\
\mathrm{H}_{\mathrm{A}}:\end{array}$} & $O L S$ & $O L S$ & Random effect \\
\hline & Fixed effect & Random effect & Fixed effect \\
\hline & $\begin{aligned} \mathrm{F}= & 12.5871^{* *} \\
& \left(\mathrm{~F}_{12,77}\right)\end{aligned}$ & $\begin{array}{c}\mathrm{LM}=12.6471 * * * \\
\left(\chi^{2}{ }_{1}\right)\end{array}$ & $\begin{array}{c}\text { Hausman }=22.0012 * * * \\
\left(\chi^{2} 8\right)\end{array}$ \\
\hline Result & Fixed model is better & Random model is better & Fixed model is better \\
\hline \multicolumn{4}{|c|}{ Model 2 (OFDI in Thailand) } \\
\hline & F Test & LM test & Hausman test \\
\hline \multirow{3}{*}{$\begin{array}{c}\text { Hypotheses } \\
\mathrm{H}_{0}: \\
\mathrm{H}_{\mathrm{A}}:\end{array}$} & $O L S$ & $O L S$ & Random effect \\
\hline & Fixed effect & Random effect & Fixed effect \\
\hline & $\begin{array}{c}\mathrm{F}=12.8184 * * \\
\left(\mathrm{~F}_{7,43}\right)\end{array}$ & $\begin{array}{c}\mathrm{LM}=20.7383 * * * \\
\left(\chi^{2}{ }_{1}\right)\end{array}$ & $\begin{array}{c}\text { Hausman }=31.2176 * * * \\
\left(\chi^{2} 7\right)\end{array}$ \\
\hline Result & Fixed model is better & Random model is better & Fixed model is better \\
\hline
\end{tabular}

Note: $*, * *, * * *$ denote statistical significance at the $10 \%, 5 \%, 1 \%$, respectively.

\subsection{Empirical Results for the Determinants of Thailand's IFDI and OFDI}

Empirical results of IFDI and OFDI determinants in Thailand are best referenced in our earlier studies, e.g., Liu and Dejphanomporn (2017) and Liu and Dejphanomporn (2018). Here, we detect and compare the differences between IFDI and OFDI determinants in Thailand to further obtain the management and policy implications for IFDI and OFDI in Thailand.

\subsubsection{Model 1 (IFDI in Thailand)}

According to Table 4, we can first find that the market size (relative per capita GDP) $\left(\beta_{1}=1.4127^{* * *}\right)$, Thailand's openness $\left(\beta_{2}=1.1615^{* * *}\right)$, relative exchange rate $\left(\beta_{4}=-0.3599 * * *\right)$, geographical distance $\left(\beta_{5}=1.0536^{* * *}\right)$ and global financial crisis $\left(\beta_{8}=-0.0189^{* *}\right)$ have significant effects on Thailand's IFDI. Therefore, the strong or main determinants of Thailand's IFDI are market size (relative per capita GDP), Thailand's openness, relative exchange rate, geographic distance, and the global financial crisis. Their estimated coefficients are significant at the level of $1 \%$ or $5 \%$. The estimated coefficients of relative wage rate $\left(\beta_{3}=-0.9379^{*}\right)$, relative 
R\&D intensity $\left(\beta_{6}=0.0939 *\right)$ and bilateral trade agreements $\left(\beta_{7}=0.1861 *\right)$ are significant at the level of $10 \%$. The estimated coefficients of political risk $\left(\beta_{8}=-\right.$ $0.199)$, Asia financial crisis $\left(\beta_{9}=0.3621\right)$ and trend factor $\left(\beta_{15}=0.0210\right)$ are nonstatistical significance. For the above-mentioned determinants of Thailand's IFDI, each explanatory variable is described in detail as follows:

Table 4: Results of Determinants of Inward and Outward FDI in Thailand by GLS

\begin{tabular}{|c|c|c|c|c|c|c|}
\hline & \multicolumn{3}{|c|}{ Model 1 (IFDI) } & \multicolumn{3}{|c|}{ Model 2 (OFDI) } \\
\hline Variable & \multicolumn{2}{|c|}{ Coefficient } & \multirow{2}{*}{$\frac{\mathrm{t} \text { Value }}{-2.68}$} & \multicolumn{2}{|c|}{ Coefficient } & t Value \\
\hline Intercept & $\beta_{0}$ & $-27.3924 * * *$ & & $\beta_{0}$ & $4.1380 * * *$ & 16.43 \\
\hline LRGDP & $\beta_{1}$ & $1.4127 * * *$ & 2.81 & $\beta_{1}$ & $0.0257 * * *$ & 2.03 \\
\hline LtOpen & $\beta_{2}$ & $1.1615 * * *$ & 2.61 & $\beta_{2}$ & $0.1957 * * *$ & 2.82 \\
\hline LRWage & $\beta_{3}$ & $-0.9379 *$ & -1.71 & $\beta_{3}$ & $0.0510 *$ & 1.89 \\
\hline LREX & $\beta_{4}$ & $-0.3599 * * *$ & -4.55 & $\beta_{4}$ & $-0.1135 * *$ & -2.31 \\
\hline LDIST & $\beta_{5}$ & $1.0536 * * *$ & 3.19 & $\beta_{5}$ & $-0.1004 * * *$ & -2.95 \\
\hline LRD & $\beta_{6}$ & $0.0939 *$ & 1.71 & $\beta_{6}$ & $0.1543 * *$ & -2.59 \\
\hline TBA & $\beta_{7}$ & $0.1861 *$ & 1.85 & $\beta_{7}$ & $0.4323 * *$ & 2.61 \\
\hline PR & $\beta_{8}$ & -0.1990 & -1.24 & & & \\
\hline $\mathrm{D}_{97}$ & $\beta_{9}$ & 0.3621 & 1.05 & & & \\
\hline $\mathrm{D}_{0814}$ & $\beta_{10}$ & $-0.0189 * *$ & -2.05 & $\beta_{8}$ & $-0.0444 * * *$ & -2.25 \\
\hline $\mathrm{Dj}$ & $\beta_{11}$ & $9.0544 * * *$ & 3.25 & $\beta_{9}$ & $0.2171 * *$ & 2.29 \\
\hline $\mathrm{Dn}$ & $\beta_{12}$ & $-5.9915 * * *$ & -3.13 & $\beta_{10}$ & $0.1226 * *$ & 2.22 \\
\hline Ds & $\beta_{13}$ & $13.1794 * * *$ & 3.09 & $\beta_{11}$ & 0.0110 & 0.77 \\
\hline $\mathrm{Du}$ & $\beta_{14}$ & $-4.8755 * * *$ & -2.85 & $\beta_{12}$ & $-0.1203^{* *}$ & -2.32 \\
\hline $\mathrm{T}$ & $\beta_{15}$ & 0.0210 & 1.01 & $\beta_{13}$ & $0.0085 * * *$ & 3.28 \\
\hline $\mathrm{R}^{2}$ & & 0.5293 & & & 0.3987 & \\
\hline Adjusted $\mathrm{R}^{2}$ & & 0.4559 & & & 0.2785 & \\
\hline F-stat $(15,74)$ & & $17.21 * * *$ & & F-stat $(13,42)$ & $13.32 * * *$ & \\
\hline Durbin-Watson & & 2.081 & & & 2.371 & \\
\hline White test & & 4.8433 & & & 3.1542 & \\
\hline Breusch-Pagan & & 4.5515 & & & 3.6241 & \\
\hline
\end{tabular}

Note: $* * *, * * *$ denotes statistical significance at the $10 \%, 5 \%, 1 \%$.

(1) Firstly, we discuss the determinants of Thailand's IFDI that are statistical significance at $1 \%$ or $5 \%$ level:

The impact $\left(\beta_{1}=1.4127 * * *\right)$ of market size (relative per capita GDP (LRGDP)) has the greatest influence on IFDI decision-making in Thailand, which is significant at the $1 \%$ level (Table 4). The market size and growing market demand encourage foreign investment in Thailand. This result is consistent with literature of Nunes, Oscategui and Peschiera (2006), which found that larger host economies tend to attract more FDI. This also means that every country that invests directly in Thailand (Japan, Hong Kong, The Netherlands, Singapore and the US) will take 
al.

into account the market size of the FDI destination.

Thailand's economic openness (LTOPEN) has a significant impact $\left(\beta_{2}=1.1615^{* * *}\right.$ ) on Thailand's IFDI at the $1 \%$ level. Foreign firms will have more opportunities to expand their business in Thailand. Not only can they access the resources and markets of the host country, they can also enter other countries on the continent by importing (exporting) their products or setting up factories in Thailand. At the same time, foreign production can replace the export of the product, but it usually stimulates domestic demand for intermediate products or raw materials. Therefore, openness has a positive impact on the outflow of foreign direct investment, the state supports less restrictive controls, and enables companies to obtain information about foreign markets. This also indicates that Thailand's policymakers may liberalize its economy to encourage foreign trade and FDI inflows in order to achieve sustained and high-speed economic growth. A previous study by Masron and Shahbudin (2010) found that openness has a strong positive impact on FDI, which supports our results.

The relative exchange rate between Thailand and the home countries (LREX) of investors (Japan, Hong Kong, the Netherlands, Singapore and the United States) has a significantly negative impact $\left(\beta_{4}=-0.3599^{* * *}\right)$ on Thailand's IFDI decision. This indicates that the depreciation of Thai currency allows foreign companies to purchase cheaper assets and technologies and reduces the relative cost of capital, thus increasing the relative wealth status of foreign companies and thereby increasing Thailand's IFDI. The results are consistent with the literature and are supported by the research finding of Masron and Shahbudin (2010).

The influence of geographic distance (DIST) has a significant positive impact $\left(\beta_{5}=1.0536^{* * *}\right)$ on Thailand's IFDI at the $1 \%$ level. The sign or direction is not what we expected. The reason is that Thailand, as one of the relatively developed countries in Southeast Asia, has more FDI governance policies and a smaller cultural distance with foreign investors, which may be a condition to support this empirical result. As the partner countries (Japan, Hong Kong, the Netherlands, Singapore and the United States) have long-term experience in foreign direct investment, they have a good relationship with Thailand in terms of trade and investment. In addition, the development of the Internet and logistics can also reduce the geographical distance effect on Thailand's IFDI. Therefore, even if the geographic distance between Thailand and the home country (Japan, Hong Kong, the Netherlands, Singapore, and the United States) is positive, the IFDI from the home country has not declined. In addition, this result is consistent with and supported by the research findings of Egger (2008). He found that if FDI is marketseeking for closer destinations, internationalizing companies are expected to prefer direct investment rather than exports. Therefore, an increase in the distance between the source country and the host country may not reduce IFDI.

The impact $\left(\beta_{10}=-0.0189^{* *}\right)$ of the global financial crisis from 2008 to 2014 ( $\left.\mathrm{D}_{0814}\right)$ on Thailand's IFDI was shown to be significantly negative, consistent with the research results of Passakornjaras (2012) and Poomlamjiak (2013). This shows that the global financial crisis has led to a decline in foreign direct investment confidence 
in Thailand by investors from Japan, Hong Kong, the Netherlands, Singapore and the United States.

In terms of country factor effects, the highest coefficients of Ds and Dj on IFDI are estimated for Singapore $\left(\beta_{13}=13.1794 * * *\right)$ and Japan $\left(\beta_{11}=9.0544^{* * *}\right)$ with positive statistical significance at $1 \%$ level. In the Netherlands $\left(\beta_{12}=-5.9915^{* * *}\right)$ and the United States $\left(\beta_{14}=-4.8755^{* * *}\right)$ of $\mathrm{Dn}$ and Du on Thailand IFDI still have statistical significance at $1 \%$ level. Results for country dummies (Thailand's home country) seem to vary in size and sign. These country effects seem to be attributed to the differences in national cultures and public policies.

(2) The following determinants that are statistical significance at $10 \%$ level:

Relative wage rate (LRWage) has a negative impact $\left(\beta_{3}=-0.9379 *\right)$ on Thailand's IFDI at a statistically significant level of $10 \%$. It is not very significant because of Thailand's cheap labor hypothesis from 1983 to 1999, but the support from 2000 to 2014 was weak. The labor cost is relatively insignificant, and the relative wage rates between Thailand and the home countries (Japan, Hong Kong, the Netherlands, Singapore and the United States) are not much different. As the intellectual capital and skills invested in Thailand's labor force in recent years are higher than in the past, it is expected to affect the relevant Thailand IFDI's decision-making. The research findings of Masron and Shahbudin (2010), Daly and Tosompark (2011) and Wattanadumrong, Collins and Snell (2014) support our results.

The effect $\left(\beta_{6}=0.0939^{*}\right)$ of relative R\&D intensity (LRD) and the effect $\left(\beta_{7}=0.1861^{*}\right)$ of bilateral trade agreement (TBA) on Thailand's IFDI are positive and significant only at the $10 \%$ level. The research findings of Haskel, Pereira, and Slaughter (2007) support the relationship between R\&D and IFDI. Our results indicate that improvements in Thailand's R\&D of manufacturing technology and management methods will affect its IFDI, although the impact is limited because Thailand's relative R\&D intensity is small compared to that of Japan, Hong Kong, the Netherlands, Singapore or the United States in this study. The positive impact of bilateral trade agreements on Thailand's IFDI shows that bilateral trade agreements are also an important determinant to increase Thailand's IFDI. Neumayer and Spes (2005) mentioned that bilateral trade agreements also guarantee a standard of treatment that can be enforced by signing such BITS (bilateral investment treaties) with developed countries through a dispute settlement mechanism between investors and states that is binding outside the domestic judicial system, especially those that are major FDI exporters and importers.

(3) The following determinants that are not statistically significance:

Regarding the political risk situation, we are concerned that the impact $\left(\beta_{8}=-0.199\right)$ of political risk (PR) on Thailand's IFDI is negative and has no statistical significance. Although the estimated coefficient is not statistically significant, as we expected, the sign is a negative effect. This negative impact of political risk may mean that lower political risk will create a more attractive and stable environment 
al.

for foreign investors. The results are consistent with studies by Abbas and Mosallamy (2016) and Daly and Tosompark (2011), who found that the political risks that occurred during this period did indeed reduce IFDI.

In terms of local conditions, the impact $\left(\beta_{9}=0.3621\right)$ of the Asian financial crisis in 1997 (D97) on Thailand's IFDI is positive and not significant. The sign is positive, contrary to what we expected. This suggests that the collapse of the Thai currency may be an increase in the purchasing power of foreign investors. After the emergence of the Thai baht in 1997 and the outbreak of the financial crisis, FDI inflows into Thailand increased. This may be due to the increase in company takeover and acquisition and the increase in the purchasing power of foreign investors due to the depreciation of Thail currency. Our result is supported by the research finding of Anuchitworawong and Thampanishvong (2014) and Abbas and Mosallamy (2016).

Finally, the influence $\left(\beta_{15}=0.0210\right)$ of time trend factor $(T)$ on IFDI is positive, but not significant. This suggests that IFDI from Japan, Hong Kong, the Netherlands, Singapore and the United States may have an increasing trend in Thailand, but this is not quite clear during our study period 1997-2014.

\subsubsection{Model 2 (OFDI in Thailand)}

Based on Table 4, we can first find that the market size (relative per capita GDP (LRGDP) $)\left(\beta_{1}=0.0257 * * *\right)$, Thailand's openness $\left(\beta_{2}=0.1957 * * *\right)$, relative exchange rate $\left(\beta_{4}=-0.1135^{* *}\right)$, geographical distance $\left(\beta_{5}=-0.1004^{* * *}\right)$, Relative $\mathrm{R} \& \mathrm{D}$ intensity $\left(\beta_{6}=0.1543^{* *}\right)$, bilateral trade agreement $\left(\beta_{7}=0.4323^{* *}\right)$ and global financial crisis $\left(\beta_{8}=-0.0444 * * *\right)$ have significant effects on Thailand's OFDI. Thus, the strong or main determinants of Thailand's OFDI are market size (relative per capita GDP), Thailand's openness, relative exchange rate, geographic distance, relative R\&D intensity, bilateral trade agreement and the global financial crisis. Their estimated coefficients are significant at the level of $1 \%$ or $5 \%$. The estimated coefficient of relative wage rate $\left(\beta_{3}=0.0510 *\right)$ is significant at the level of $10 \%$. The estimated coefficients of country effect from Singapore $\left(\beta_{11}=0.0110\right)$ is nonstatistical significance. For the above-mentioned determinants of Thailand's OFDI, each explanatory variable is also described in detail as follows:

(1) Firstly, we discuss the determinants of Thailand's OFDI that are statistical significance at $1 \%$ or $5 \%$ level:

Still according to the empirical results shown in Table 4, we find that the impact $\left(\beta_{1}=0.0257^{* * *}\right)$ of the host country's market size (relative per capita GDP (LRGDP)) on Thailand has a positive statistically significant coefficient at the $1 \%$ level. This means that higher market potential, higher purchasing power of local residents and higher market demand give Thai companies more opportunities to achieve economies of scale and reduce production costs in the host country. In addition, the market size that affects FDI may also have an agglomeration effect, which is an important factor for Thai companies to make overseas investments. This result is 
consistent with and supported by previous studies of Nunes, Oscategui and Peschiera (2006) and Daly and Tosompark (2011) who found that the larger the economic scale of the host country is, the more Thailand's OFDI is.

The degree of openness of Thailand (LTOPEN) has a positive effect $\left(\beta_{2}=0.1957 * * *\right)$ on OFDI, which is significant at $1 \%$ level. This means that Thailand's OFDI complements its international trade when foreign subsidiaries use domestic inputs to produce output in the host country. Daly and Tosompark (2011) also believed that FDI outflow would lead to export substitution effect and export support effect. Foreign production can replace exports of the product, but usually stimulates domestic demand for intermediate goods or raw materials. Thailand's greater openness can reduce restrictive controls and enable companies to obtain information on foreign markets where FDI flows out of Thailand. Previous studies by $\mathrm{Ng}$ (2010) also found a significant relationship between the economic openness and OFDI, which supported our results.

The relative exchange rate (LREX) has a significant negative influence $\left(\beta_{4}=\right.$ $0.1135^{* *}$ ) on Thailand's OFDI at the significance level of 5\%. This means that the increase in relative production costs caused by the appreciation of the host country's relative exchange rate will reduce the OFDI of Thai enterprises to the host country. This information suggests to investors that the depreciation of the host country currency should facilitate the outflow of Thai FDI from the host countries (Japan, Hong Kong, the Netherlands, Singapore and the US), where the exchange rate changes are fully passed on to production costs, as production costs abroad have fallen. This result is also supported by the research findings of previous study of Masron and Shahbudin (2010).

The influence $\left(\beta_{5}=-0.1004^{* * *}\right)$ of geographical distance (DIST) on Thailand's OFDI is negatively significant at $1 \%$ level. This shows that the farther the distance between Thailand and the host country, the more Thailand's OFDI decreases. This important implication suggests that Thailand's OFDI decisions take into account transport costs and even transaction costs, such as information costs or time to learn about institutional factors (trade regulation, political systems, language, religion and social customs), which are potential barriers to capital flows. This result is supported by gravity models and is consistent with the findings of previous studies such as Fratianni, Marchionne and Oh (2011) and Leibrecht and Riedl (2014).

The relative $R \& D$ intensity (LRD) has a positive impact $\left(\beta_{6}=0.1543^{* *}\right)$ on Thailand's OFDI at 5\% significant level. The results indicate that the increase of R\&D intensity in the host country is the main attraction for Thai enterprises to invest abroad. This means that more R\&D intensity in the host country attracts Thailand's outward investment in order to obtain higher manufacturing and management expertise from the host country. Specifically, in recent years, Thailand's OFDI has been used to acquire advanced proprietary technology (know-how), strategic assets (such as brands, local distribution networks) and other capabilities abroad by considering the relative of R\&D intensity between the two countries, hence leading to an increase in Thailand's OFDI. Our results are supported by the research finding of Lee (2011). 
al.

Bilateral trade agreement (TBA) has a positive and significant impact $\left(\beta_{7}=0.4323^{* *}\right)$ on Thailand's OFDI at the level of $5 \%$. This shows that bilateral trade agreements are also an important determinant of the increase in Thailand's OFDI. Bilateral trade agreements can also increase international trade and outward direct investment, despite the different conditions and policies of host countries in different regions. In contrast, the global financial crisis from 2008 to 2014 ( $\left.\mathrm{D}_{0814}\right)$ proved to have a negative impact $\left(\beta_{8}=-0.0444 * * *\right)$ on Thailand's OFDI decisions at $1 \%$ significant level. This shows that the global financial crisis leads to a decline in Thai investors' confidence in the host country's OFDI, which is also supported by the result of previous study of Alfaro and Chen (2012).

Regarding the country factor effect, the highest coefficients of $\mathrm{Dj}$ and Dn on OFDI are estimated to be Japan $\left(\beta_{9}=0.2171^{* *}\right)$ and the Netherlands $\left(\beta_{10}=0.1226^{* *}\right)$, which have a positive statistically significant impact at the $5 \%$ level. The Du for the United States $\left(\beta_{12}=-0.1203^{* *}\right)$ has a negative impact at the $5 \%$ statistical significance level. As for the influence of country factors, the size and direction of the country dummies (from Thailand to the host country) seem to vary. It seems that country effects are, after all, due to the differences in national cultures and public policies.

The time trend factor $\left(\beta_{13}=0.0085^{* * *}\right)$ shows the increasing trend of OFDI over time, which has a positive and statistically significant effect at the $1 \%$ level. This shows that during the period of our study from 2004 to 2014, Thailand has a significant trend of increasing OFDI of Japan, Hong Kong, the Netherlands, Singapore and the United States.

(2) The following determinants that are statistical significance at 10\% level: Lower wage rate (LRWage) is attractive to foreign cross-border investment. In our research, the relative wage rate has a positive impact $\left(\beta_{3}=0.0510^{*}\right)$ on Thailand's OFDI, but only at a significance level of $10 \%$. The positive sign seems to indicate that OFDI from Thailand is increasing even when the relative wage rate between the host country and Thailand is high. It is also argued in the literature that a positive relationship is possible because the wage rate can be seen as a signal of labor quality. Higher wage rate may mean higher skilled labor, human and intellectual capital or management skills (Daly and Tosompark, 2011) that Thailand investors seek to learn through their OFDI countries (Japan, Hong Kong, The Netherlands, Singapore and the United States).

(3) The following determinants that are not statistically significance:

In terms of country factor effect, Singapore (Ds) has a positive effect on Thailand's OFDI $\left(\beta_{11}=0.0110\right)$, but the effect is not significant compared with the effect of Japan $(\mathrm{Dj})$, the Netherlands (Dn) and the United States $(\mathrm{Du})$ as we have indicated above. The reason may be that Thailand's OFDI to Singapore is smaller than those of the three countries. 
It should be noted that overall, as indicated in Table 4, the empirical models estimated by GLS have shown goodness of fit since $\mathrm{R}^{2} 0.5293,0.3987$; adjusted $\mathrm{R}^{2}$ $0.4559,0.2785$ and F-Statistics 17.21 (at 15, 74 degree of freedom), 13.32 (at 13, 42 degrees of freedom) in Model 1 and 2 respectively, which passed the test at the significance level of 1\%. By checking Durbin-Watson statistics 2.081, 2.371, White statistics 4.8433, 3.1542 and Breusch-Pagan statistics 4.5515, 3.6241 in Model 1 and 2 respectively, we found that none of the estimated error terms showed autocorrelation or heteroscedasticity. This information also indicates that the above discussions of these determinants affecting IFDI and OFDI in Thailand are appropriate.

\section{Concluding Remarks}

The main findings and vital implications of this study are summarized as follows:

\subsection{Main Findings and Comparisons for the Determinants of Thailand's IFDI and OFDI}

\subsubsection{Main Findings}

Regarding to the determinants of Thailand's IFDI, the empirical results indicate that market size (relative per capita GDP), Thailand's openness, geographical distance, bilateral trade agreements and relative R\&D intensity have positive and statistically significant effects on Thailand's IFDI. Relative exchange rate, global financial crisis and relative wage rate have negative and statistically significant effects, while Asian financial crisis and Thailand's political risk have insignificant effects on Thailand's IFDI. As for the determinants of Thailand's OFDI, the results show that the market size (relative per capita GDP), Thailand's openness, relative real wage, relative R\&D intensity, bilateral trade agreement have positive and statistically significant effects on Thailand's OFDI. Relative exchange rates, geographical distance, global financial crisis have negative and statistically significant effect on Thailand's OFDI.

\subsubsection{Comparisons}

In comparison, the determinants of IFDI and OFDI in Thailand have different influences due to the country's different economy and development level. The most important determinant of attracting Thailand's IFDI is the size of the market. While the most important determinant of Thailand's OFDI is bilateral trade agreements, Thailand must use bilateral trade agreements as a tool to help Thailand make it easier and break down barriers to invest in more developed countries (such as Japan, Hong Kong, the Netherlands, Singapore and the United States). In Thailand's IFDI and OFDI, the effects of relative wage rate and geographical distance are opposite. Lower relative wage rate has attracted more IFDI to Thailand.

For Thai enterprises, OFDI to more developed countries is an opportunity to obtain skilled talent and labors (employees), which can enhance the degree of globalization of enterprises. Geographical distance has a negative impact on Thailand's OFDI, 
al.

which seems to be a potential obstacle to Thailand's OFDI. However, the development of the Internet and logistics can reduce the impact of geographical distance on Thailand's IFDI and OFDI. In addition, the impact of the global financial crisis has a significant negative impact on both IFDI and OFDI, with a greater impact on OFDI. This suggests that the global financial crisis has led to a decline in Thai investors' confidence in OFDI in more developed host countries and their inability to attract IFDI from Japan, Hong Kong, the Netherlands, Singapore or the United States.

\subsection{Managerial and Policy Implications for Thailand's IFDI and OFDI 4.2.1 Implications for Thailand's IFDI}

In order to attract Thailand's IFDI, it is necessary to consider expanding its market size through GDP expansion, maintaining a higher level of openness of international trade and investment, and passing legislative trade policies or negotiating international (bilateral) trade agreements. Improvements in the relative R\&D of manufacturing technology and management methods are also important for influencing foreign companies' decision to operate FDI in Thailand.

The relative exchange rates between Thailand and its home countries (Japan, Hong Kong, the Netherlands, Singapore and the United States) have a significantly negative impact on Thailand's IFDI. This information suggests that in the case where exchange rate changes are fully passed on to production costs, the depreciation of the local currency should increase FDI inflows, since local production costs have fallen when FDI flows into Thailand. In the context of relatively low Labor costs and small differences in relative wage rates between Thailand and the home countries (Japan, Hong Kong, the Netherlands, Singapore and the United States), investment in the intellectual capital and skills of the Thailand's Labor force is expected to influence the relevant decisions on Thailand's IFDI.

In this research, geographical distance has a significant and positive impact on IFDI in Thailand. Businesses or government sectors may consider that the development of the Internet and logistics can also reduce the impact of geographical distance on Thailand's IFDI. Hence, although the effect of geographical distance between Thailand and its home country (Japan, Hong Kong, the Netherlands, Singapore and the United States) on IFDI is positive, Thailand's IFDI from its home country can avoid decline. Taking into account the negative impact of special events such as the global financial crisis and local political risks on Thailand's IFDI, this means that when Thailand faces political and financial risks, IFDI will be reduced. Businesses or government sectors should pay attention to financial and political risks. The addition of dummy variables for country factor effect has different impacts on Thailand's IFDI, and it is necessary to consider country-specific factors to attract Thailand's IFDI from different countries. 


\subsubsection{Implications for Thailand's OFDI}

In order to promote Thailand's OFDI, market size (measured by the relative per capita GDP) between the host country and Thailand is the most important determinant of OFDI. The market size and growing market demand of the host countries (Japan, Hong Kong, the Netherlands, Singapore, and the United States) can encourage Thailand to expand OFDI. Thailand's degree of openness (measured as the ratio of exports plus imports to GDP) is another key point in boosting OFDI. With the expansion of import and export flows, Thailand's higher level of openness will promote more OFDI. Thailand's openness can support less restrictive controls and enable companies to obtain information about foreign markets. For the Thailand government, it can support Thailand's import and export sectors to promote OFDI by adjusting tariff barriers to maintain the level of openness and legislating trade policies or international trade agreements. Bilateral trade agreements signed between Thailand and host countries are important determinants of promoting Thailand's OFDI. Although host countries are characterized by different conditions and policies, signing bilateral trade agreements can increase international trade and Thailand's OFDI.

The relative exchange rate between the host country and Thailand has a significantly negative impact on Thailand's OFDI decision. In cases where exchange rate changes are fully passed on to production costs, the depreciation of the host country's currency should facilitate the OFDI from Thailand to the host country as foreign production costs have fallen. The relative wage rates of host countries to Thailand are significantly positive, indicating that higher wage rates may mean that Thailand investors seek higher skilled labor (human and intellectual capital or managerial skills) and learn from their OFDI host countries. Thailand's OFDI to Japan, Hong Kong, the Netherlands, Singapore and the United States provide an opportunity for Thailand companies to upgrade their technology. In this research, from the perspective of the relative R\&D intensity on Thailand's OFDI, the increase in the relative R\&D intensity of the host country will drive Thailand's OFDI. In order to promote Thailand's OFDI to the host countries, business or government sectors can consider higher R\&D intensity of host countries in manufacturing technology, management knowledge, advanced know-how and strategic assets (such as brand, local distribution network) and other capabilities to drive OFDI.

The geographical distance has a negative impact on Thailand's OFDI. The policy implication is that Thailand needs to consider transportation costs and even transaction costs when making OFDI decisions, such as information costs and taking time to understand the institutional factors (e.g., trade regulations, political systems, language, religion, and social customs) that lead to potential obstacles to capital outflows. In this study, the global financial crisis has significant negative influence on Thailand's OFDI. Firms or government sectors should concern about financial risks. The addition of country dummies variables has shown different country factor effects (size and direction) on Thailand's OFDI, country-specific factors need to be involved in promoting Thailand's OFDI to different countries. 
al.

It should be noted that although the determinants of Thailand's IFDI were studied during 1997-2014, whereas the determinants of Thailand's OFDI were analyzed during 2004-2014. Since their overlap period is still more than ten years, they will not deviate from the comparative effect. In sum, the findings of this study may contribute additional facts to support or enhance the theories of FDI. It also provides policy or managerial strategic implications for the Thailand government and related investors to develop appropriate FDI policies or strategies to attract IFDI and promote OFDI.

\section{References}

[1] Abbas, S. and Mosallamy, D. E. (2016). Determinants of FDI Flows to Developing Countries: An Empirical Study on the MENA Region. Journal of Finance and Economics, 4(1), 30-38.

[2] Alfaro, L. and Chen, M. X. (2012). Surviving the Global Financial Crisis: Foreign Direct Investment and Establishment Performance. American Economic Journal: Economic Policy, American Economic Association, 4(3), 30-55.

[3] Anuchitworawong, C. and Thampanishvong, K. (2014). Determinants of Foreign Direct Investment in Thailand: Does Natural Disaster Matter? International Journal of Disaster Risk Reduction, 9, 48-57.

[4] Chantapong, S. and Thanabodee, S. (2012). Thai Direct Investment in the Neighboring Countries: An Important Step to AEC. Bangkok.

[5] Dacharux, K., Leelapornchai, P. and Udomkerdmongkol, M. (2009). Thailand's Investment in the Post-Crisis Era: Issues and Challenges (pp. 347385).

[6] Dunning, J. H. (1993). Multinational Enterprises and the Global Economy. Wokingham, UK.: Addision-Wesley.

[7] Fratianni, M. U. Marchionne, F. and Oh, C. H. (2011). A Commentary on the Gravity Equation in International Business Research. Multinational Business Review, 19(1), 36-46.

[8] Haskel, J. E., Pereira, S. C. and Slaughter, M. J. (2007). Does Inward Foreign Direct Investment Boost the Productivity of Domestic Firms? The Review of Economics and Statistics, 89(3), 482-496.

[9] Im, K. S., Pesaran, M. H. and Shin, Y. (2003). Testing for Unit Roots in Heterogeneous Panels. Journal of Econometrics, 115(1), 53-47.

[10] Jaiblai, P. and Shenai, V. (2019). The Determinants of FDI in Sub-Saharan Economies: A Study of Data from 1990-2017. International Journal of Financial Studies, 7(3), 43.

[11] Lee, C. Y. (2011). The Differential Effects of Public R\&D Support on Firm R\&D: Theory and Evidence from Multi-Country Data. Technovation, 31(5), 256-269. 
[12] Leibrecht, M. and Riedl, A. (2014). Modeling FDI Based on a Spatially Augmented Gravity Model: Evidence for Central and Eastern European Countries. The Journal of International Trade and Economic Development, 23(8), 1206-1237.

[13] Levin, A., Lin, C. F. and Chu, C. S. J. (2002). Unit Root Tests in Panel Data: Asymptotic and Finite-Sample Properties. Journal of Econometrics, 108(1), 124.

[14] Liu, H. H. and Dejphanomporn, P. (2017). On the Determinants of Outward Foreign Direct Investment: Empirical Evidences from Thailand. International Research Journal of Finance and Economics, 161, 105-119.

[15] Liu, H. H. and Dejphanomporn, P. (2018). Development of Inward Foreign Direct Investments in Thailand: Determinants, Effects and Implications. Asian Economic and Financial Review, 8(6), 717-732.

[16] Masron, T. A. and Shahbudin, A. S. M. (2010). Push Factors of Outward FDI: Evidence from Malaysia and Thailand. Journal of Business and Policy Research, 5(1), 54-68.

[17] Neumayer, E. and Spes, L. (2005). Do Bilateral Investment Treaties Increase Foreign Direct Investment to Developing Countries? World Development, 33(10), 1567-1585.

[18] Ng, J. (2010). The Political Economy of Democracy and FDI Inflows in Oil Countries. (Masters Degree), Columbia University, New York.

[19] Nnamdi, I. S. and Eniekezimene, D. E. (2018). Foreign Direct Investment Inflows and Economic Performance in a Developing Economy: Nigerian Evidence. European Journal of Business and Management, 10(6), 104-113.

[20] Nunes, C. L., Oscategui, J. and Peschiera, J. (2006). Determinants of FDI in Latin America. Documento De Trabajo, 252, 57-76.

[21] Pananond, P. (2007). The Changing Dynamics of Thai Multinationals after the Asian Economic Crisis. Journal of International Management, 13(3), 356-375.

[22] Passakornjaras, S. (2012). Thailand's Outward Foreign Direct Investment: The Case of the Garment Industry. ASEAN Economic Bulletin, 29(2), 101-115.

[23] Pongpattananon, N. and Annonjarn, C. (2012). Thailand's Direct Investment: How to Overcome Obstacles. Thailand: Bank of Thailand.

[24] Poomlamjiak, B. (2013). The Causal Relationship between GDP, Exports, Energy Consumption, and $\mathrm{CO} 2$ in Thailand and Malaysia. (MasterTheies), Chinese Culture University, Taiwan.

[25] Sermcheep, S. (2013). Foreign Direct Investment and Economic Growth: The Case of Thailand's Inward and Outward FDI. (Master's degree), Chulalongkorn University, Thailand.

[26] Sova, R., Albu, L. L., Stancu, I. and Sova, A. (2009). Patterns of Foreign Direct Investment in the New EU Countries. Romanian Journal of Economic Forecasting, 2, 2-51.

[27] Trkulja, J. (2005). Geographic Factors as Determinants of Foreign Direct Investment in Eastern Europe's Transitioning Economies. Honors Projects: 4. 
al.

[28] Tomiura, E. (2003). Firm-Level Relationship between Technological Capability and Foreign Direct Investment. Discussion Paper Series No.138. Research Institute for Economics and Business Administration, Kobe University, Kobe, Japan.

[29] Wattanadumrong, B., Collins, A. and Snell, M. C. (2014). Taking the Thai Trail: Attracting FDI via Macro-Level Policy. Journal of Policy Modeling, 36(6), 1135-1151.

[30] Wee, K. H. (2007). Outward Foreign Direct Investment by Enterprises from Thailand. Transnational Corporations, 16(1), 89-116.

Appendix A: Variable Descriptions of Thailand's IFDI

\begin{tabular}{|c|c|c|c|c|}
\hline Symbol & Determinants & Measures & $\begin{array}{c}\text { Expected } \\
\text { Effect }\end{array}$ & $\begin{array}{c}\text { Data } \\
\text { Source }\end{array}$ \\
\hline LIFDI & Inward FDI & $\begin{array}{c}\text { Annual inflows into Thailand } \\
\text { from five FDI partner } \\
\text { countries }\end{array}$ & & Bank of Thailand (BOT) \\
\hline LRGDP & Relative GDP & $\begin{array}{c}\text { Relative GDP between } \\
\text { Thailand and home countries }\end{array}$ & Positive & $\begin{array}{l}\text { Trading Economics } \\
\text { (2015) }\end{array}$ \\
\hline LTOPEN & $\begin{array}{l}\text { Thailand's } \\
\text { Openness }\end{array}$ & $\begin{array}{l}\text { Ratio of Thailand's exports } \\
\text { plus imports to GDP }\end{array}$ & Positive & $\begin{array}{l}\text { Trading Economics } \\
(2015), \text { World Bank }\end{array}$ \\
\hline LRWage & $\begin{array}{l}\text { Relative wage } \\
\text { rate }\end{array}$ & $\begin{array}{c}\text { Relative wages between } \\
\text { Thailand and home countries } \\
\text { (hourly compensation in US } \\
\text { dollars) }\end{array}$ & Negative & $\begin{array}{l}\text { The Conference Board, } \\
\text { International Labor } \\
\text { Comparisons program } \\
\text { (December 2014) }\end{array}$ \\
\hline LREX & $\begin{array}{c}\text { Relative } \\
\text { Exchange rate }\end{array}$ & $\begin{array}{c}\text { Relative exchange rate } \\
\text { between Thailand and home } \\
\text { countries }\end{array}$ & Negative & $\begin{array}{l}\text { Trading Economics } \\
\text { (2015) }\end{array}$ \\
\hline LDIST & $\begin{array}{l}\text { Geographical } \\
\text { Distance }\end{array}$ & $\begin{array}{c}\text { Natural logarithm of spatial } \\
\text { distance between the capitals } \\
\text { of Thailand and home } \\
\text { countries }\end{array}$ & Negative & CEPTII \\
\hline LRD & $\begin{array}{l}\text { Relative R\&D } \\
\text { Intensity }\end{array}$ & $\begin{array}{c}\text { Relative R\&D intensity } \\
\text { between Thailand and home } \\
\text { countries }\end{array}$ & Positive & World Bank \\
\hline TBA & $\begin{array}{c}\text { Bilateral Trade } \\
\text { Agreement }\end{array}$ & $\begin{array}{l}\text { Number of bilateral } \\
\text { agreements signed by } \\
\text { Thailand }\end{array}$ & Positive & UNCTAD \\
\hline PR & Political Risk & $\begin{array}{c}\text { Political Risks in Thailand } \\
(2004,2009,2013-2014)\end{array}$ & Negative & \\
\hline D97 & $\begin{array}{l}\text { Asian Financial } \\
\text { Crisis }\end{array}$ & $\begin{array}{c}\text { Asian Financial Crisis } \\
(1996-1998)\end{array}$ & Negative & \\
\hline D0814 & $\begin{array}{l}\text { World Financial } \\
\text { Crisis }\end{array}$ & $\begin{array}{l}\text { Subprime Mortgage and } \\
\text { Financial Tsunami } \\
(2008-2014)\end{array}$ & Negative & \\
\hline
\end{tabular}


Appendix B: Variable Descriptions of Thailand's OFDI

\begin{tabular}{|c|c|c|c|c|}
\hline Symbol & Determinants & Measures & $\begin{array}{l}\text { Expected } \\
\text { Effect }\end{array}$ & $\begin{array}{l}\text { Data } \\
\text { Source }\end{array}$ \\
\hline LOFDI & Outward FDI & $\begin{array}{l}\text { Annual outflow from Thailand } \\
\text { to five FDI partner countries }\end{array}$ & & $\begin{array}{l}\text { Bank of Thailand } \\
\text { (BOT) }\end{array}$ \\
\hline LRGDP & Relative GDP & $\begin{array}{l}\text { Relative GDP between host } \\
\text { country and Thailand }\end{array}$ & Positive & $\begin{array}{l}\text { Trading Economics } \\
\text { (2015) }\end{array}$ \\
\hline LtOPEN & $\begin{array}{l}\text { Thailand's } \\
\text { Openness }\end{array}$ & $\begin{array}{c}\text { Ratio of Thailand's exports plus } \\
\text { imports to GDP }\end{array}$ & Positive & $\begin{array}{l}\text { Trading Economics } \\
\text { (2015), World Bank }\end{array}$ \\
\hline LRWage & $\begin{array}{l}\text { Relative wage } \\
\text { rate }\end{array}$ & $\begin{array}{c}\text { Relative wages between host } \\
\text { country and Thailand } \\
\text { (hourly compensation cost in } \\
\text { US dollars) }\end{array}$ & Negative & $\begin{array}{l}\text { The Conference Board, } \\
\text { International Labor } \\
\text { Comparisons program } \\
\text { (December 2014) }\end{array}$ \\
\hline LREX & $\begin{array}{c}\text { Relative } \\
\text { Exchange rate }\end{array}$ & $\begin{array}{l}\text { Relative exchange rate between } \\
\text { host country and Thailand }\end{array}$ & Negative & $\begin{array}{l}\text { Trading Economics } \\
\text { (2015) }\end{array}$ \\
\hline LDIST & $\begin{array}{l}\text { Geographical } \\
\text { Distance }\end{array}$ & $\begin{array}{c}\text { Natural logarithm of spatial } \\
\text { distance between the capitals of } \\
\text { host country and Thailand }\end{array}$ & Negative & CEPTII \\
\hline LRD & $\begin{array}{l}\text { Relative R\&D } \\
\text { Intensity }\end{array}$ & $\begin{array}{c}\text { Relative R\&D intensity } \\
\text { between host country and } \\
\text { Thailand }\end{array}$ & Positive & World Bank \\
\hline TBA & $\begin{array}{c}\text { Bilateral Trade } \\
\text { Agreement }\end{array}$ & $\begin{array}{l}\text { Number of bilateral agreements } \\
\text { signed by Thailand }\end{array}$ & Positive & UNCTAD \\
\hline PR & Political Risk & $\begin{array}{l}\text { Political Risks in Thailand } \\
(2004,2009,2013-2014)\end{array}$ & Negative & \\
\hline D0814 & $\begin{array}{l}\text { World Financial } \\
\text { Crisis }\end{array}$ & $\begin{array}{c}\text { Subprime Mortgage and } \\
\text { Financial Tsunami (2008-2014) }\end{array}$ & Negative & \\
\hline
\end{tabular}

